\title{
GENERATION Z AND GENERATION X SMART BANKING SERVICES RESISTANCE
}

\author{
Dr. Hem Chand Jain
}

Officiating Principal, Deen Dayal Upadhayaya College, University of Delhi, New Delhi, India

\section{Anubha Godara}

Research Scholar, Department of Commerce, Delhi School of Economics, University of Delhi, New Delhi, India

\begin{abstract}
Smart banking services are supposed to be the endeavor of the progressive times. Generation Zis the Tech-Savvy generation while Generation $X$ is the adaptable one, both being offered the global platform of services at their fingertip. The smart banking services usage is yet lacking amongst both these generations. The study focuses on the factors behind the resistance prevailing in these generations. The data of 261 respondents have been analyzed from Rajasthan to examine the existing barriers of Smart Banking Services. The psychological and functional barriers have been studied from the Innovation Resistance Theory by Ram and Sheth.
\end{abstract}

Key words: Generation Z, Generation X, Smart Banking Services, Resistance factors, Innovation resistance.

Cite this Article: Hem Chand Jain and Anubha Godara, Generation Z and Generation X Smart Banking Services Resistance, International Journal of Management, 11(12), 2020, pp. 2800-2806.

http://iaeme.com/Home/issue/IJM?Volume=11\&Issue=12

\section{INTRODUCTION}

Generation $\mathrm{Z}$ has quite been known for their choices and flexible approach, whereas Generation $\mathrm{X}$ is the cautious and informational learning generation known for its motivational inspiration (Ashoka and Vinay,2017).The age of a person describes to a certain extent, his behavior pattern and the choices made by him along with the preferences being chosen. The banking advancement across these generations is also influenced by their generation gap. Just as their saving habits differ, and so their priorities of usage and hindrance. According to the Pew Research Centre,2020 the Generation Z has the habit of credit expenditure, Generation X prefers to only spend as much as they earn. The segregation of the generation is explained as under:

- Generation Z-This generation group comprises of people aged from 5-25 years, born between 1995-2015. 
- Generation X-This generation is composed of the people aged 41-55 years who were born from 1965-1979.

\section{REVIEW OF LITERATURE}

The both these generations have different preferences for the accessibility of the services, while the generation $\mathrm{Z}$ prefers to procure in-depth knowledge before the actual usage, whereas that is not the case with the Generation $X$ who are interested in knowing the process and procedure beforehand (Aggarwal H., and Vaghela P.S.,2019).Even though Generation X has exposure to the risk-taking environment, they are conservative (Ashoka and Vinay,2017). Since there exist major differences in the behavior patterns of both these generations, this paper seeks to study their smart banking usage and the barriers, if any dominating amongst such users. The Ram and Sheth Model (1989), of "Consumer Resistance to Innovation" has been used to derive the constructs for the study. The resistance factors-implied as the various barriers as usage, value, and risk barriers based upon their functionality resistance factor and upon the psychological factors are the traditional and image barriers.

The usage barrier is said to be in existence when there is any hindrance in the usage of smart banking services. The constituents of the usage barrier are as under:

- Easy to use

- Convenient to use

- Faster to use

- Progressive usage

- Need of usage

The risk barrier is prevalent when the risk presumed poses functionality abruption. The risk barrier comprises of:

- Screen size

- Connection error

- Wrong information

- Information theft

- Stability

The value barrier dominates when the comparison of the benefit derived from such function is unable to exceed the cost incurred in such adoption. It has five variables as mentioned below:

- Economical

- Advantageous

- Better control

- Time and space challenges

- Internet usage cost

- Smart device cost 
The traditional barrier happens to prevail when the respondents prefer the traditional ways of banking over smart banking services. This barrier comprises of:

- Reliability

- Mandatory

- Customer Service

- Bank Visit

The image barrier exists due to the preconceived notion in the mind of the consumer of smart banking services. It has the following constituents:

- Phishing accidents fear

- Technology impression

- Good impression

\section{PROBLEM STATEMENT AND OBJECTIVE OF THE STUDY}

Since the behavior of the individuals is affected by their variables, thus even age could be a significant factor in determining the resistance and the factors of it in the smart bankingservices. Thus, the study aims:

- To measure the smart banking usage and resistance across Generation $\mathrm{Z}$ and Generation $\mathrm{X}$ in Rajasthan.

- To ascertain the barriers across Generation $\mathrm{Z}$ and Generation $\mathrm{X}$ of smart banking services.

\section{RESEARCH METHODOLOGY}

\subsection{Type of Research: Exploratory Research} Data Source:

a. Primary Data from respondents categorized as Generation $\mathrm{Z}$ and Generation $\mathrm{X}$ through the survey method.

Target Population: Generation Z and Generation X of Rajasthan, from the Generation X and central districts.

Sample size:256 Customers using the banking services in Rajasthan, as the primary sampling unit.

Sampling Technique: Stratified Random Sampling.

Tool: Structured questionnaire has been used for the primary data collection.

Data Analysis Tool: Given the composition and structure of the data, the independent sample T-test has been used, to determine the effect of the selected age groups on the various resistance groups.

Further, for the analysis, the IBM SPSS has been used for the independent sample T-test.

\section{HYPOTHESIS FORMULATION}

1.H0: The usage barrier does not vary across the Generation $Z$ and Generation $X$.

$\mathrm{H} 1$ : The usage barrier varies across Generation $\mathrm{Z}$ and the Generation $\mathrm{X}$

2.H0: The risk barrier does not differ across Generation $Z$ and Generation $X$.

H1: The risk barrier does vary across the Generation Z and Generation X. 
3.H0: The value barrier differs across Generation $\mathrm{Z}$ and Generation $\mathrm{X}$.

$\mathrm{H} 1$ : The value barrier varies across Generation $\mathrm{Z}$ and Generation $\mathrm{X}$.

4.H0: The traditional barrier does not vary across the Generation $\mathrm{Z}$ and Generation $\mathrm{X}$.

H1: The traditional barrier does vary across the Generation Z and Generation X.

5.H0: The image barrier does not vary with Generation $Z$ and Generation X.

H1: The image barrier differs across Generation Z and Generation X.

\section{ANALYSIS}

\subsection{Reliability}

Table 1 Reliability Analysis

\begin{tabular}{|l|l|l|}
\hline Constructs & Cronbach's Alpha & Number of Items \\
\hline Usage Barrier & 0.767531 & 5 \\
\hline Value Barrier & 0.897628 & 6 \\
\hline Risk Barrier & 0.747539 & 5 \\
\hline Tradition Barrier & 0.867247 & 4 \\
\hline Image Barrier & 0.773496 & 3 \\
\hline
\end{tabular}

To check the internal consistency of the constructs, the Cronbach's alpha has been determined. Since the values generated are below 0.7 as per Hair et al., (2006), the constructs have been considered to be reliable.

\subsection{Smart Banking Services Resistance Analysis}

The cross-tabulation has been used to measure the usage and resistance amongst Generation $\mathrm{Z}$ and Generation X.

Table 2 SBS * Age Cross Tabulation

\begin{tabular}{|c|c|c|c|c|c|}
\hline & & & Age & & Total \\
\hline & & & $5-25$ & $41-55$ & \\
\hline & & Count & 22 & 33 & 55 \\
\hline $\mathrm{CDC}$ & 10 & $\%$ within Age & $18 . \%$ & $20 \%$ & $18 \%$ \\
\hline נימה & & Count & 100 & 136 & 236 \\
\hline & & $\%$ within Age & $82 \%$ & $80 \%$ & $81 \%$ \\
\hline & & Count & 122 & 169 & 291 \\
\hline Iotal & & $\%$ within Age & $100 \%$ & $100 \%$ & $100 \%$ \\
\hline
\end{tabular}

According to table 2, the respondents who are not using smart banking services i.e., resistance towards the smart banking services are higher amongst Generation $\mathrm{Z}$ as compared to Generation X. Overall, the usage of both the age groups is less, with $81 \%$ joint non-usage. 


\subsection{Independent Sample T-Test}

Since the means of two independent variables are to be compared across the dependent variables, the Independent Sample T-test has been applied for further analysis:

Table 3 Independent Samples Test

\begin{tabular}{|c|c|c|c|c|c|c|c|c|c|c|}
\hline & \multicolumn{2}{|c|}{ 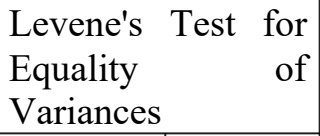 } & \multicolumn{7}{|c|}{ t-test for Equality of Means } \\
\hline & & \multirow[t]{2}{*}{$\mathrm{F}$} & \multirow[t]{2}{*}{ Sig. } & \multirow[t]{2}{*}{$\mathrm{t}$} & \multirow[t]{2}{*}{ df } & \multirow[t]{2}{*}{$\begin{array}{l}\text { Sig. (2- } \\
\text { tailed) }\end{array}$} & \multirow[t]{2}{*}{$\begin{array}{l}\text { Mean } \\
\text { Differenc } \\
\mathrm{e}\end{array}$} & \multirow[t]{2}{*}{$\begin{array}{l}\text { Std. Error } \\
\text { Differenc } \\
\text { e }\end{array}$} & \multicolumn{2}{|c|}{$\begin{array}{l}95 \% \text { Confidence } \\
\text { Interval of the } \\
\text { Difference }\end{array}$} \\
\hline & & & & & & & & & Lower & Upper \\
\hline \multirow{2}{*}{$\begin{array}{l}\text { Usage } \\
\text { barrier }\end{array}$} & $\begin{array}{l}\text { Equal variances } \\
\text { assumed }\end{array}$ & .067473 & .795263 & .648 & 254.00 & .517497 & -.098455 & .151910 & -.397618 & .200708 \\
\hline & $\begin{array}{l}\text { Equal variances } \\
\text { not assumed }\end{array}$ & & & .647 & 222.65 & .518221 & -.098455 & .152143 & -.398279 & .201370 \\
\hline \multirow{2}{*}{$\begin{array}{l}\text { Risk } \\
\text { barrier }\end{array}$} & $\begin{array}{l}\text { Equal variances } \\
\text { assumed }\end{array}$ & .084301 & .771788 & -1.02 & 254.00 & .308781 & .117755 & .115465 & -.345146 & .109637 \\
\hline & $\begin{array}{l}\text { Equal variances } \\
\text { not assumed }\end{array}$ & & & -1.02 & 226.14 & .307500 & .117755 & .115131 & -.344621 & .109112 \\
\hline \multirow{2}{*}{$\begin{array}{l}\text { Value } \\
\text { barrier }\end{array}$} & $\begin{array}{l}\text { Equal variances } \\
\text { assumed }\end{array}$ & 1.154735 & .283580 & -.491 & 254.00 & .623743 & -.059287 & .120711 & -.297009 & .178434 \\
\hline & $\begin{array}{l}\text { Equal variances } \\
\text { not assumed }\end{array}$ & & & -.484 & 211.84 & .628911 & -.059287 & .122504 & -.300769 & .182195 \\
\hline \multirow{2}{*}{$\begin{array}{l}\text { Traditi } \\
\text { onal } \\
\text { barrier }\end{array}$} & $\begin{array}{l}\text { Equal variances } \\
\text { assumed }\end{array}$ & .056600 & .024368 & .072 & 254.00 & .042196 & .005992 & .083548 & -.158542 & .170526 \\
\hline & $\begin{array}{l}\text { Equal variances } \\
\text { not assumed }\end{array}$ & & & .071 & 220.55 & .042196 & .005992 & .083896 & -.159349 & .171332 \\
\hline \multirow{2}{*}{$\begin{array}{l}\text { Image } \\
\text { barrier }\end{array}$} & $\begin{array}{l}\text { Equal variances } \\
\text { assumed }\end{array}$ & 2.678953 & .040139 & .654 & 254.00 & .034215 & -.069946 & .106980 & -.280626 & .140733 \\
\hline & $\begin{array}{l}\text { Equal variances } \\
\text { not assumed }\end{array}$ & & & .672 & 242.77 & .034215 & -.069946 & .104121 & -.275042 & .135149 \\
\hline
\end{tabular}

According to the results in Table 3, the Levene's test is significant for the Traditional barrier (.024368) and Image barrier (.040139), therefore we can assume unequal variances within the two groups. Since p-value for traditional barrier (.042196) and image barrier (.034215), which is less than .05 , thus the t-test reveals a significant difference between the age groups Generation $\mathrm{Z}$ and the Generation $\mathrm{X}$. Thus, the null hypothesis for the traditional and image barrier is rejected.

While the usage barrier, risk barrier, value barrier does not show any significant impact of the age upon the barrier, value, and risk barrier. Thus, the null hypothesis for usage barriers, value barriers and risk barriers is accepted.

\subsection{Hypothesis Analysis}

Constructs: Hypothesis supported

Usage barrier: The barrier does not have any difference across both the age groups

Risk barrier: The barrier is not affected by the generation difference between Generation $\mathrm{Z}$ and Generation X

Value barrier: The barrier does not have vary due to the different age groups

Traditional barrier: Generation $\mathrm{Z}$ and Generation $\mathrm{X}$ have a varying effect on the traditional barrier. 
Image barrier: There is a difference in the barrier between Generation $\mathrm{Z}$ and Generation $\mathrm{X}$ Image barrier: There is a difference in the barrier between Generation $\mathrm{Z}$ and Generation $\mathrm{X}$

\section{RESULTS}

- The resistance of the smart banking services prevails even amongst Generation $\mathrm{Z}$ and Generation X in Rajasthan.

- The usage barrier does not vary amongst Generation Z and Generation X in Rajasthan.

- The risk barrier is not varying with the variation in Generation $\mathrm{Z}$ and the Generation $\mathrm{X}$ across Rajasthan.

- The value barrier did not have any specific impact of Generation Z and Generation X, differently.

- The traditional barrier varies across Generation $\mathrm{Z}$ and Generation X in Rajasthan.

- Generation $\mathrm{Z}$ and Generation $\mathrm{X}$ have a different impact across the image barrier.

\section{IMPLICATIONS}

The study states that the resistance across the Generation $\mathrm{Z}$ and Generation $\mathrm{X}$ have been high, thus the measure to ensure the inclusive adoption must be taken. There is the resistance across both the generations even though the variation due to the age exists in the image barrier and traditional barrier. Thus, there are differences across the psychological resistance barriers and not across the functional resistance barriers. Thus, to overcome these barriers the stereotypes existing amongst the people should be taken care of the fear of phishing accidents and the hand on technology usage experience does not seem to be favoring the image of the smart banking services amongst Generation $Z$ and the Generation X. Since there has been an effect of the Generation $\mathrm{Z}$ and Generation $\mathrm{X}$ age group on the traditional barrier thus, the reliability of the respondents on the smart banking services is posing a problem in its adoption. Self-assisted customer services are also not much preferred by the respondents. The mandatory services usage and the preferred bank visit to sort the issues or perform banking services are contributing to the smart banking services resistance. Thus, the findings of the study help determine the improvisation required for the better inclusion of smart banking services.

\section{LIMITATIONS}

- The study focuses on only respondents of the 5-25 and 25-40 age groups only.

- The area of the study, being only one state i.e., Rajasthan.

- Due to the time and resource constraints, the study has been undertaken on the 291 respondents of the state.

\section{CONCLUSION}

The selected customer groups reflected the barrier of the differential choices existing due to the image barrier and the traditional barrier. The resistance did not differ across Generation $\mathrm{Z}$ and the Generation $X$ because of the usage barrier, risk, and value barrier i.e., the resistance is not due to the functionality of the smart banking services but due to the psychological resistance factors. The study can be used by the banking practitioners and the policymakers to do away with the psychological barriers existing. Thus, the psychological aspect can be considered for the further integration of smart banking services. 


\section{REFERENCES}

[1] Agarwal, H. \&. (2018). WORK VALUES OF GEN Z:Bridging the Gap to the Next Generation. National Conference on Innovative Business Management Practices in the 21st Century, (pp. 126). Gujarat.

[2] Ashoka, M. a. (2017). Customer Acceptance of Millennial Generation Banking Services: Challenges and Prospects (March 8, 2017). 1-13.

[3] Chouk I., M. Z. (2019). Factors for and against resistance to smart services: the role of consumer lifestyle and ecosystem related variables. Journal of Services Marketing, 1-16.

[4] Hair, J. F. (2006). Multivariate data analysis. Uppersaddle River.

[5] Jain, Y. (2013). Mobile banking: A study on adoption and challenges in southern Rajasthan, India. International Journal of Research and Development,2, 902-914.

[6] Sheth, R. a. (1989). Consumer resistance to innovations: the marketing problem and its solutions. Journal of Consumer Marketing, Vol. 6 No. 2, 5-14. 